\title{
The Regulatory Framework for Safety Management Systems in Airworthiness Organisations
}

\author{
Eranga Batuwangala *,+(D), Jose Silva ${ }^{\dagger}$ and Graham Wild *,+(D) \\ School of Engineering, Aerospace and Aviation Discipline, RMIT University, Melbourne, VIC 3000, Australia; \\ jose.silva@rmit.edu.au \\ * Correspondence: s3576656@student.rmit.edu.au (E.B.); graham.wild@rmit.edu.au (G.W.); \\ Tel.: +61-422-123-938 (E.B.) \\ t These authors contributed equally to this work.
}

Received: 31 August 2018; Accepted: 1 November 2018; Published: 7 November 2018

\begin{abstract}
In recent years, a growing emphasis on safety has driven various industries, both in manufacturing and service, to implement a Safety Management System (SMS) in their organisations. SMSs have also been widely implemented in aviation due to both regulatory requirements and voluntary implementation with the aim of decreasing incidents and accidents whilst reducing inefficiencies and costs stemming from the repercussions of safety failures. The aviation industry involves various players for the provision of services ranging from airline operations, maintenance, aerodrome operations, air traffic services, aircraft and component design, manufacturing, and training. Not all organisations in the aviation industry have implemented SMSs. Furthermore, SMS is currently not regulated for all aviation organisations. Whilst technology has played a key role in driving down the number of accidents and incidents in aviation, the growth in air traffic demands having programs in place to further drive down accident rates. In this context, this article provides an investigation to the regulatory framework for the implementation of SMSs in aviation, including the requirements stipulated by the International Civil Aviation Organisation (ICAO) and the status of SMS regulation of key National Aviation Authorities (NAA) and Military Aviation Authorities (MAA), with a focus on organisations involved in airworthiness including initial and continuing airworthiness. This article also investigates the challenges of implementing SMSs in organisations involved in Airworthiness, as well as the benefits that could be gained by service providers as well as NAA's or MAA's through SMSs.
\end{abstract}

Keywords: safety management system; human error; airworthiness; design organization

\section{Introduction to Safety and Safety Management Systems in Aviation}

Air transport is growing rapidly with the 2017 statistics of 4 billion air travellers expected to nearly double in the next 15 years [1]. The forecasted traffic of nearly 60 million scheduled passenger flights expected in 2030 compared to 35 million in 2016 will result in over two commercial air transport accidents per week if the same accident rate of 2016 [2] prevails in 2030. This strongly suggests that growth in air traffic requires a parallel effort in aviation safety to reduce accident rates. Air transport is considered the safest way to travel, even with rapid growth in air traffic demands, and technological developments which have resulted in complex aircraft systems. To maintain safety into the future, novel programs and tools will play an increasingly important role in enhancing aviation safety and reducing safety occurrences. In aviation an incident is defined as a safety occurrence, less severe than an accident, associated with the operation of an aircraft which affects or could affect the safety of operation. An accident is defined as an occurrence associated with the operation of an aircraft in which a person is either fatally or seriously injured, or the aircraft sustains damage, experiences structural 
failure, or is lost/missing/completely inaccessible. A more detailed definition is provided in ICAO Annex 19 [3].

The meaning of the word "safety" varies based on the context of its usage and has different definitions in various industries. In aviation, safety means the state in which risks associated with aviation activities, related to, or in direct support of the operation of aircraft, are reduced and controlled to an acceptable level [3]. There are many notable academics and industry experts who have contributed to the evolution of safety in many industries and environments. Jens Rasmussen was a pioneer in the field of safety science for the last quarter of the 20th century specialising in the study of human factors [4]. In the 1980s, Rasmussen proposed a framework with three levels of human performance: skill-based, rule-based, and knowledge-based [5]. James Reason, a research psychologist who has published multiple books and papers, has produced ground-breaking work discussing human error. His book Human Error [6], dedicated to Jens Rasmussen, is said to be a masterpiece in phycological writing [7]. The famous "Swiss-Cheese" model, developed by Reason to illustrate how accidents involve successive breaches of multiple system defences, is widely used by safety specialists as an accident causation model. Since the first flight by the Wright brothers in 1903, aviation safety has progressed through three main eras [8]:

1. the technical era (from the early days of aviation until the 1960s) where safety deficiencies were mainly attributed to technological failures,

2. the human factors era (from the 1970s to the 1990s) when the focus of safety extended to include human factors issues, most notably human-human and human-machine interfaces, and

3. the organisational era (from the 1990s to the present), encompassing organisational factors in addition to human and technical factors.

More recently, and resulting from an increasing level of maturity in aviation safety, an emerging era of "Total Aviation System Approach" requires all aviation stakeholders and their interfaces to be understood and managed for the purpose of safety performance [8]. In addition, this concept of implementation of safety management by various stakeholders and service providers offers a more proactive approach to safety compared to the traditionally reactive approaches to aviation safety adopted in the past.

A Safety Management System (SMS) is a systematic approach to managing safety, including the necessary organisational structures, accountabilities, policies, and procedures [3]. SMSs have evolved from a combination of concepts in system safety, quality management systems, and other inputs [9]. Implementation and maintenance of an SMS have been either voluntary due to its recognition as an industry best practice for safety or due to regulatory compliance. Whilst SMS is widely applied in various industries especially those with high safety risks or complex operations such as oil and gas, construction, electricity generation, highways etc., it has also been actively implemented in aviation in the last decade. The main contributor to this is the standardisation of SMS requirements for aviation by the International Civil Aviation Organisation (ICAO), and the obligation of member States to comply with ICAO standards and recommended practices. SMS provides a framework of methodologies, tools and requirements that help organisations to understand the safety concepts, to construct and customise a management system that is best suited to achieve the required safety outcomes for each organisation. Whilst safety management was previously used as a tool to improve occupational health and safety [9], it has evolved into a much broader system encompassing technological, organisational, social, and psychological approaches to safety and systems thinking. The latest approach taken by ICAO is a total systems approach which considers the entire aviation industry as a system and all entities as sub-systems [8].

Though accidents were mainly attributed to technical failures in the early days of aviation, developments in technology have progressively led to more reliable systems, therefore shifting the interest of safety experts from the 1990s towards the role of human factors as contributory factors to accidents [7]. In fact, human error still holds the largest share of accident causal factors with 
a contribution of about $70 \%$ [10], therefore stressing the need to include adequate human factors training as a key component of current SMSs. Human factors affect aviation safety during various stages of the aircraft or system life cycle, from design, manufacture, operation, and maintenance to disposal [11]. Due to the safety of flights largely depending on the pilots operating the aircraft, there is an abundance of research into human factors and human error mainly in the context of aircraft flight operations [12-16]. Research has also been conducted on human error during air traffic control operations [17-19], aircraft maintenance [20,21], and the aerodrome operational environment [22]. Human error management tools, maintenance error decision tools, and human factor related accident investigation tools are actively used by aviation service providers as part of their safety management systems. An example of these tools is the Human Factors Analysis and Classification System (HFACS), which was developed for investigating and analysing the human causes of aviation accidents in both the military and civil domains [23-25]. In addition to this, the PEAR model considers people, environment, actions, and resources in relation to human factors in aviation maintenance [26], while the SHELL model provides a conceptual tool to analyse the interaction of multiple system components including software, hardware, environment, and liveware [27]. Another widely used tool is the Maintenance Error Decision Aid (MEDA) introduced by Boeing [28]. It is observed, however, that there is less research on management tools that may be more applicable to organisations involved in initial and continuing airworthiness functions including aircraft design, manufacture, and continuing airworthiness management.

This article presents an investigation of the aviation regulatory framework for the implementation of SMSs in organisations involved in various functions of aviation. Whilst previous research has been conducted on the comparison of military airworthiness regulatory frameworks [29], there is no published research found specifically on the adequacy and scope of aviation regulatory frameworks for the implementation of SMS covering different types of service providers. This paper presents a review of the SMS regulations of key aviation stakeholders with reference to the ICAO framework for SMSs, together with the challenges and benefits of implementing SMSs by aviation service providers involved in airworthiness functions.

\section{An Overview of the ICAO Framework for SMS}

The ICAO Annexes provide Standards and Recommended Practices (SARPS) to be enforced or adopted by States' National Aviation Authorities (NAA) as regulations or as industry best practices for civil aviation. While signatory States are required to regulate aviation in accordance with ICAO SARPS for Civil Aviation, Military Aviation Authorities (MAA) are also aligning their regulations in accordance with ICAO SARPS wherever practicable. ICAO Annex 19, first published in July 2013 (which became applicable in November 2013) [30], is dedicated to Safety Management. Annex 19 provides standards for the implementation and maintenance of a State Safety Program (SSP) by States, as well as for the provisioning of a Safety Management System (SMS) by applicable service providers involved in the various services and industries in aviation. Service providers will be regulated by the NAA or other nominated authority within each State. Prior to the publication of the first edition of Annex 19, SMS requirements existed across various ICAO Annexes and documents. The provisions to the 1st edition of Annex 19 were developed in accordance with recommendations provided by the Directors General of Civil Aviation Conference on a Global Strategy for Aviation Safety (Montréal, 20 to 22 March 2006) (DGCA/06) and the High-level Safety Conference (Montréal, 29 March to 1 April 2010) (HLSC /2010) regarding the need for an Annex dedicated to safety management. ICAO recognises that effective implementation of an SSP and implementation of an SMS by the service providers is a gradual process and is dependent on the complexity of air transportation and the level of maturity of the oversight capabilities of each State. The degree and method of implementation of ICAO Annexes vary in each State. A study conducted on aerodromes in EASA member States (2008-2010) indicated that the implementation of SMS requirements represented challenging demands on the authorities as well as the aerodromes [31]. However, under article 38 of the Convention [32], contracting States are 
required to notify ICAO of any differences between their national regulations and practices and the standards contained in a given Annex and any amendments thereto.

Edition 2 to ICAO Annex 19 was published in 2016, the provisions of which will become applicable by November 2019 [3]. Edition 2 provides amendments mainly capturing further developments of safety management provisions and the extension of safety management system (SMS) provisions to organisations responsible for the type design and/or manufacture of engines and propellers. Safety management under the provisions of Annex 19 complements ICAO's Global Aviation Safety Plan (GASP), Doc 10004 [33] and is supported by the Safety Management Manual, Doc 9589 [27] which provides guidance for the development, implementation, and maintenance of an SSP by the State and an SMS by individual organisations operating as aviation service providers.

Annex 19 is applicable to safety management functions related to, or in direct support of, the safe operation of aircraft [3]. It provides a generic list of requirements that is not specific to any particular aviation function or service provider or organisation.

In accordance with ICAO Annex 19, Edition 2, Chapter 3, through the SSP, States are required to ensure that the following service providers implement an SMS within their organisations [3]:

1. Approved Training Organisations that operate in accordance with Annex 1.

2. Operators of airplanes or helicopters authorized to conduct international commercial air transport in accordance with Annex 6, Part I or Part III (section II).

3. Approved Maintenance Organisations, providing services to operators of airplanes or helicopters engaged in international air transport in accordance with Annex 6, Part I or Part III (section II).

4. Organisations responsible for the type design or manufacture of aircraft, engines or propellers in accordance with Annex 8.

5. Air Traffic Services (ATS) providers in accordance with Annex 11.

6. Operators of certified aerodromes in accordance with Annex 14, Volume I.

It should be noted that the SMS framework was applicable to organisations responsible for type design and manufacture of aircraft with edition 1 of ICAO Annex 19. Edition 2 of the said Annex which becomes applicable by November 2019, has broadened this scope to organisations responsible for the design and manufacture of engines and propellers. The operators of aircraft (airplanes or helicopters) authorised to conduct international commercial air transport services in accordance with Annex 6 are required to ensure continuing airworthiness of aircraft. Furthermore, the State of Registry and State of Operator are responsible for ensuring that the operators develop or adopt requirements for continuing airworthiness. Thereby the operators' obligations for SMS implementation are extended to continuing airworthiness functions.

The ICAO specified framework for the implementation and maintenance of an SMS comprises of four main components and twelve elements as the minimum requirement. The framework can be used for the implementation of an SSP by the State, as well as for the implementation of an SMS by a State's aviation service providers by tailoring in accordance with the complexity and nature of the business of each organisation. These four main components and elements are [3]:

1. Safety policy and objectives

1.1. Management commitment

1.2. Safety accountability and responsibilities

1.3. Appointment of key safety personnel

1.4. Coordination of emergency response planning

1.5. SMS documentation

2. Safety risk management

\subsection{Hazard identification}


2.2. Safety risk assessment and mitigation

3. Safety assurance

3.1. Safety performance monitoring and measurement

3.2. The management of change

3.3. Continuous improvement of the SMS

4. Safety promotion

4.1. Training and education

4.2. Safety communication

Sharing and exchange of safety information is encouraged for global safety improvements, incident and accident prevention and safety standardization; this also forms a fundamental component of ICAO's GASP [33]. An equally important requirement is the protection of safety data and safety information, without which sharing and exchange of information cannot be promoted, and the continued availability of data and information cannot be expected. Whilst this is an industry concern, it is broadly addressed by the "Code of Conduct on the Sharing and Use of Safety Information" documented in the GASP [33] and supplemented by the "Principles for the protection of safety data, safety information and related sources" in Annex 19 [3]. However, the adequacy of Annex 19 and Doc $9859[3,33]$ addressing the concerns on the protection of safety data and safety information has been questioned by the aviation industry [34].

\section{Safety Management International Collaboration Group (SM-ICG)}

With the purpose of promoting a common understanding of SMS and facilitating its implementation across aviation internationally, the SM-ICG has been formed and comprises of many aviation authorities including the Federal Aviation Administration (FAA) of the United States, the European Aviation Safety Agency (EASA) of the European Union, the Civil Aviation Safety Authority (CASA) of Australia, the Transport Canada Civil Aviation (TCCA), the Civil Aviation Authority of United Kingdom (UK CAA), the Civil Aviation Authority of New Zealand (CAA NZ), the Aviation Safety and Security Agency (AESA) of Spain, the National Civil Aviation Agency (ANAC) of Brazil, the Civil Aviation Authority of the Netherlands (CAA NL), the Civil Aviation Authority of Singapore (CAAS), the Civil Aviation Department of Hong Kong (CAD HK), the Direction Générale de l'Aviation Civile (DGAC) of France, the Ente Nazionale per l'Aviazione Civile (ENAC) of Italy, the Federal Office of Civil Aviation (FOCA) of Switzerland, the Finnish Transport Safety Agency (Trafi), the Irish Aviation Authority (IAA), Japan Civil Aviation Bureau (JCAB), and the United Arab Emirates General Civil Aviation Authority (UAE GCAA), together with ICAO as an observer to the group [35]. Members of the group collaborate on common SMS/SSP topics of interest, whilst sharing products and lessons learnt in the implementation of SMS/SSP, which encourage the progression of a harmonized SMS across the international aviation community.

\section{Status of Regulation and Implementation of SMS-A Global Review}

Some States or countries have implemented an SSP and other States are in the process of implementation. Under the SSP, a nominated national authority which in most States is the NAA will have oversight on SMS implementation and maintenance by aviation service providers that are required to have an SMS as per the regulations of each State. SMS implementation varies worldwide in terms of regulatory enforcement as well as maturity. It is up to each NAA to determine the regulatory requirements and the timings of applicability of SMS for each aviation function. In most States, SMSs are mandated mainly for service providers that are in operational functions of aviation. Most States are yet to regulate SMSs explicitly for organisations engaged in airworthiness including initial and continuing airworthiness, whilst a few States are in the process of rulemaking for this 
sector, and some have taken the approach of promoting voluntary implementation of SMSs ahead of regulation. Continuing airworthiness may be considered as part of the operator's responsibilities, thereby in certain cases may be implicitly covered by the SMS requirements for an operator of commercial air transport. However, the Defence Aviation Safety Authority (DASA) of Australia has explicitly mandated SMSs for organisations engaged in initial and continuing airworthiness [36].

Some States have regulations specifically for SMSs, whilst some capture this as part of advisory publications or have embedded within individual regulations applicable for various aviation service providers. In most cases, a degree of flexibility prevails within the regulation for the implementation of SMSs, allowing organisations to implement SMSs by integrating already existing and proposed programs, policies or procedures including components of existing System Safety Programs (SSP) and management systems such as quality management systems (QMS) and Security Management Systems (SeMS). This may be the preferred option for some organisations to avoid duplication of processes and resources. Furthermore, organisations that provide multiple services under sub-entities within the parent organisation such as commercial air transport, aircraft maintenance, component maintenance, and aviation design may implement a common SMS across various sub-entities. Thereby in these cases, the SMSs implemented mainly for the requirement of the organisation's commercial air transportation would cover initial and continuing airworthiness organisations as well. Most NAAs would allow the service providers to tailor the SMSs in accordance with the nature of the business, the complexity of operations, activities and size of the organisations, within the broad framework of SMS components and elements provided in ICAO Annex 19.

Table 1 provides a comparison of the status of SMS regulations of the following key aviation authorities, including civil and military sectors. Specifically:

- Civil Aviation Safety Authority (CASA), Australia [37],

- Defence Aviation Safety Authority (DASA), Australia [36],

- European Aviation Safety Agency (EASA), European Union [38],

- European Defence Agency (EDA), European Union [39],

- Federal Aviation Administration (FAA), United States [40],

- US Air Force (USAF) [41,42], and

- $\quad$ Transport Canada (TC), Canada [43]

The scope of the review has been limited to the above-mentioned aviation authorities due to limitations in accessibility to data in the public domain and language constraints.

A comparison of SMS regulation status by key aviation authorities, considering only the fully regulated status for each service provider category is given in Figure 1. This indicates that all authorities listed, both civil and military, have regulated SMSs for operators engaged in regular public transport (or commercial air transport) and military air operations. A further review of regulations reveals this is applicable for both domestic and international operations. ICAO Annex 19 requires that those operators who conduct international commercial air transport in accordance with Annex 6, Part I or Part III (section II) to implement an SMS, and this requirement is well addressed through regulation by the aviation authorities. There are also considerable regulations on SMSs for maintenance organisations as well as air navigation service providers and aerodrome operators, which is also in line with the requirements of Annex 19. Therefore, it is evident that most authorities have focused more on SMS regulations for organisations involved in the operational environments of aviation. 
Table 1. Status of SMS regulation under key NAA and MAA (as at June 2018).

\begin{tabular}{|c|c|c|c|c|c|c|c|}
\hline & CASA & DASA & EASA & EDA & FAA & USAF & TC \\
\hline SSP Implemented & Yes & $\mathrm{N} / \mathrm{A}$ & Some States under EU & $\mathrm{N} / \mathrm{A}$ & Yes & $\mathrm{N} / \mathrm{A}$ & Yes \\
\hline Regulation on SMS & $\begin{array}{l}\text { Various CAO, AC, } \\
\text { and CAAP }{ }^{1}\end{array}$ & DASR SMS & $\begin{array}{c}2018 / 1139 \\
\text { (As Management Systems which } \\
\text { include safety risk management) }\end{array}$ & \multirow{9}{*}{ Work in Progress } & FAR Part 5 & Air Force SMS—AFI 91-202 & $\begin{array}{c}\text { CAR Part } \\
1 \text {-Subpart } 7\end{array}$ \\
\hline $\begin{array}{l}\text { Approved Flight or Pilot } \\
\text { Training Organisations }\end{array}$ & $\begin{array}{l}\text { No Published } \\
\text { Information }\end{array}$ & $\begin{array}{l}\text { No Published } \\
\text { Information }\end{array}$ & $\begin{array}{l}\text { Regulated (for ATPL-MPL-CPL } \\
\text { and Type Rating) }{ }^{2}\end{array}$ & & $\begin{array}{l}\text { Voluntary } \\
\text { Implementation-Pending } \\
\text { Regulation } \\
\end{array}$ & \multirow{8}{*}{$\begin{array}{l}\text { SMS is Integrated into USAF Mishap } \\
\text { Prevention Program applicable to USAF } \\
\text { MAJCOMs/FOAs/DRU }\end{array}$} & $\begin{array}{l}\text { No Published } \\
\text { Information }\end{array}$ \\
\hline $\begin{array}{l}\text { Approved Maintenance } \\
\text { Training Organisations }\end{array}$ & $\begin{array}{l}\text { No Published } \\
\text { Information }\end{array}$ & $\begin{array}{l}\text { No Published } \\
\text { Information }\end{array}$ & Rulemaking in process & & $\begin{array}{c}\text { Voluntary } \\
\text { Implementation-Pending } \\
\text { Regulation } \\
\end{array}$ & & $\begin{array}{l}\text { No Published } \\
\text { Information }\end{array}$ \\
\hline $\begin{array}{l}\text { Commercial Air Transport } \\
\text { Operators or Military Operators } \\
\text { (as applicable) }\end{array}$ & Regulated & Regulated & $\begin{array}{l}\text { Regulated as a requirement for } \\
\text { Management System }\end{array}$ & & Regulated & & Regulated \\
\hline $\begin{array}{l}\text { Approved Maintenance } \\
\text { Organisations }\end{array}$ & Regulated & Regulated & Rulemaking in process & & $\begin{array}{c}\text { Voluntary } \\
\text { Implementation-Pending } \\
\text { Regulation }\end{array}$ & & Regulated \\
\hline $\begin{array}{l}\text { Approved Design \& Production } \\
\text { Organisations }\end{array}$ & $\begin{array}{l}\text { No Published } \\
\text { Information }\end{array}$ & Regulated & Rulemaking in process & & $\begin{array}{l}\text { Voluntary } \\
\text { Implementation-Pending } \\
\text { Regulation }\end{array}$ & & $\begin{array}{l}\text { Rulemaking in } \\
\text { process }\end{array}$ \\
\hline $\begin{array}{l}\text { Continuing Airworthiness } \\
\text { Management Organisations } \\
\text { (CAMO) }\end{array}$ & $\begin{array}{l}\text { No Published } \\
\text { Information }\end{array}$ & Regulated & Rulemaking in process & & Not Applicable & & $\begin{array}{l}\text { No Published } \\
\text { Information }\end{array}$ \\
\hline $\begin{array}{l}\text { Air Traffic/Air Navigation } \\
\text { Service Providers }\end{array}$ & Regulated & $\begin{array}{c}\text { Rulemaking in } \\
\text { process }\end{array}$ & Regulated & & Regulated & & Regulated \\
\hline $\begin{array}{l}\text { Aerodrome Operators and } \\
\text { Airport Operators }\end{array}$ & Regulated & $\begin{array}{l}\text { Rulemaking in } \\
\text { process }\end{array}$ & Regulated & & $\begin{array}{l}\text { Voluntary } \\
\text { Implementation-Pending } \\
\text { Regulation }\end{array}$ & & Regulated \\
\hline
\end{tabular}

1 Tables (AC 139-16(1); CAO 82.3, CAO 82.5, CAAP: SMS-1(0); SMS-2(0) SMS-3(0) SMS-4(0)). ${ }^{2}$ Some alleviations for LAPL, PPL, SPL, and BPL. List of Abbreviations in Table 1; AC: Advisory Circular; ATPL: Airline Transport Pilot License; BPL: Balloon Pilot License; CAAP: Civil Aviation Advisory Publication; CAO: Civil Aviation Order; CASA: Civil Aviation Safety Authority; CPL: Commercial Pilot License; DASA: Defence Aviation Safety Authority; DASR: Defence Aviation Safety Regulation; DRU: Direct reporting Unit; EASA: European Aviation Safety Agency; EDA: European Defence Agency; EU: European Union; FAA: Federal Aviation Administration; FOA: Field Operating Agencies; LAPL: Light Aircraft Pilot License; MAA: Military Aviation Authority; MAJCOM: Major Commands; MPL: Multi-Crew Pilot License; NAA: National Aviation Authority; PPL: Private Pilot License; SMS: Safety Management System; SPL: Sailplane Pilot License; SSP: State Safety Program; TC: Transport Canada; USAF: US Air Force. 


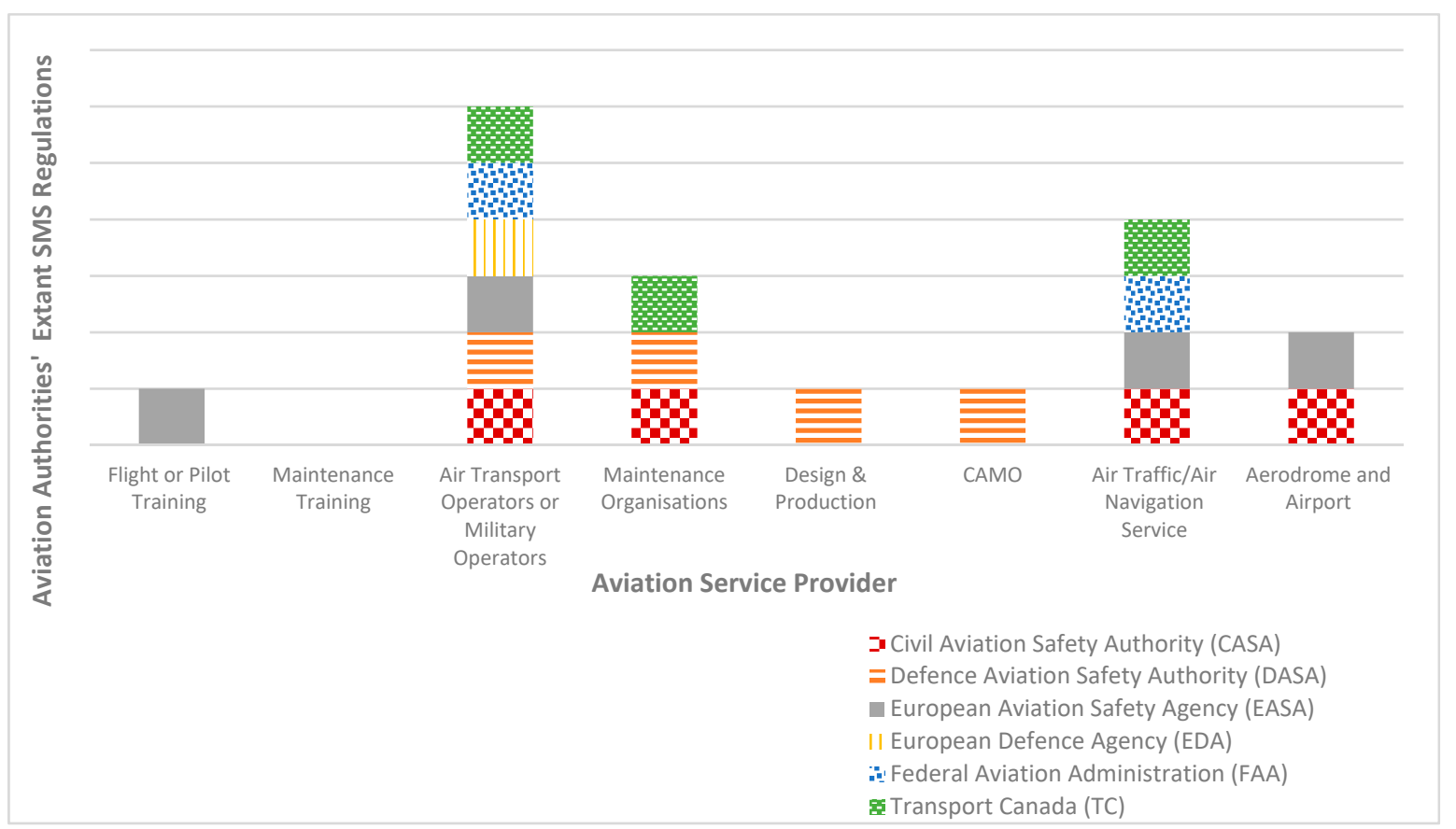

Figure 1. A comparison of Safety Management System regulations under key Aviation Authorities (as at June 2018).

Regulations on SMSs for approved design and production organisations as well as for those involved in continuing airworthiness management (CAMO) are in the process of being regulated, or not yet regulated, with DASA being the only authority to have regulated SMS in CAMO and design organisations out of those considered for comparison in Table 1. The main factor for this inconsistency in SMS regulation for various service providers would be the difference in each organisation's operational context. For those organisations involved in highly complex and hazardous operational environments, the impact of non-compliance with safety requirements or human error might have a direct or immediate consequence, whereas any safety non-compliance or human error has a more latent nature in initial or continuing airworthiness organisations. Furthermore, system certification provides a process of assuring system safety. Regulations pertaining to aircraft and system design, airworthiness codes, industry standards, and system safety engineering methods that govern the system certification process mainly consider the aspect of "design product" or "design output". Examples of existing standards include:

- Aviation regulations, such as Federal Aviation Regulation (FAR) 25 [44] or EASA Certification Specification (CS) 25 [45],

- System safety engineering practices and standards, such as Society of Automotive Engineers Aerospace Recommended Practice (SAE ARP) 4754 [46] or ARP 4761 [47], and United States Military (MIL) standard 882 [48].

However, these do not address organisational management systems for safety including organisational processes and human behavioural aspects of employees of initial and continuing airworthiness organisations. In this regard, implementation of SMSs in these organisations will play a vital role in filling these gaps of safety management, which ultimately affect product safety during various stages of its life cycle.

Responsibilities for continuing airworthiness of aircraft lie with the aircraft operator as well as the design organisation. Although Continuing Airworthiness Management Organisations (CAMO) are not specifically listed in Annex 19, most aviation authorities have regulated continuing airworthiness management functions and the requirement of a CAMO for this purpose. Some authorities are also considering SMS implementation in CAMOs in their current or proposed regulations. Furthermore, 
Annex 19 requires SMSs for design organisations only if they are responsible for the type design or manufacture of aircraft, engines or propellers. However, some authorities have already regulated or considering regulations that require all approved design organisations to implement an SMS.

A detailed review of SMS implementation regulations or instructions and those specific to airworthiness organisations are discussed below for EASA, FAA, CASA, and DASA. Aviation authorities of many countries are currently quite active with regards to regulating and promoting SMS. Further to their notable role in the development and implementation of SMS, the scope of this review is limited to the above-mentioned aviation authorities due to limitations in the availability of data in the public domain and language constraints.

\subsection{EASA}

EASA has recently repealed Basic Regulation EC No. 216/2008 with the issuance of Basic Regulation EC No. 2018/1139 which includes the authority requirement for EU member States to have an SSP as per ICAO Annex 19. Prior to this, some member States had voluntarily implemented an SSP [49]. The new Basic Regulation also emphasises key aspects of SMSs but frames it as management systems in a more general sense [45].

SMS rulemaking for initial and continuing airworthiness, under rulemaking tasks RMT.0251 and RMT.0251(b) [50,51] are in progress for the introduction of SMS into the requirements of design, production, and maintenance organisations by 2020 . EASA is also intending to introduce a new Part-CAMO to align with SMS requirements for continuing airworthiness management. This part would be an Annex to Commission Regulation (EU) No. 1321/2014, regulating CAMOs which are managing the aircraft of licensed air carriers or operators of complex motor-powered aircraft (CMPA). Furthermore, subsequent to the approval of Opinion 07/2016, EASA will also adopt a risk-based approach to EASA's determination to the Level of Involvement (LOI) in product certification based on each organisation's performance in airworthiness and environmental certification of aircraft and related products, parts and appliances together with design changes and repairs. The intention here is that the level of oversight on the design organisation by EASA be 'performance-based' (Ref Opinion 07/2016 and NPA 2017-20). These requirements of SMSs will be updated within the respective regulation (EU) No. 748/2012 for organisations involved in initial airworthiness.

EASA is adopting a two-phased approach for SMS rulemaking for airworthiness organisations:

- Phase I-Introduction of SMS requirements in Part-M Continuing Airworthiness Management Organisation,

- Phase II-Introduction of SMS requirements in Part-145 Maintenance Organisations and Part-21 Design and Production Organisation.

Phase I, under RMT.0251 (MDM.055) will primarily focus on SMSs in CAMO and adapt EC No. 1321/2014 to include SMSs. During Phase II under RMT.0251(b) (MDM.055-MDM.060), SMSs in CAMO would be already regulated and implemented by Phase I and the primary focus would move to implementing SMS in Part-145 and Part-21 organisations.

The European Plan for Aviation Safety (EPAS) is a regional program at European level, which aligns the safety priorities with EASA's strategic plan and integrates the input received from stakeholders and aviation service providers in the region.

\subsection{FAA}

FAA 14 CFR Part 5 details the requirements for SMSs. In accordance with FAR Part 5, SMSs are currently applicable to commercial air carriers that conduct domestic, flag, and supplemental operations under FAR Part 121. FAA has been working to implement SMSs in other sectors of aviation, and in the interim promote voluntary implementation. These include Part 135 operators, Part 21 Design and Manufacturing Organisations, Part 141 pilot schools, Part 142 training schools, and Part 145 maintenance, repair, and overhaul (MRO) facilities. Guidance material and standards have 
been made available for use by the aviation industry. FAA's national policy on SMSs is documented in several FAA Orders and Advisory Circulars.

Under current FAA 14 CFR Part 21 regulations (Certification procedures for products and articles) the terminology Type Certificate Holder is used rather than Design Organisation. SMS rule-making for 14 CFR Part 21 was launched in 2014, led by the Aircraft Engineering Division's System Performance and Development Branch (AIR-150), which has taken the feedback received through the Manufacturers SMS (MSMS) Pilot Project and the Part 21/SMS Aviation Rulemaking Committee (ARC) to help develop the rulemaking package. Currently FAA, is in the process of developing a Notice of Proposed Rule Making (NRPRM) for Part 21 that will include requirements for SMSs in design and manufacturing organisations in the US. In the interim, a voluntary SMS program has been instituted by the FAA for design and manufacturing organisations in accordance with an industry standard (NAS 9927) [52] developed by Aerospace Industries Association (AIA) and General Aviation Manufacturers Association (GAMA). This standard uses FAA 14 CFR Part 5 as the basis for SMS requirements. The FAA has recognised this standard as meeting the intent of ICAO Annex 19 and 14 CFR Part 5. The Voluntary SMS Program will further allow the FAA to assess applicant voluntary SMS programs in accordance with the Standard or 14 CFR Part 5.

\subsection{CASA}

Although a separate regulation on SMSs has not yet been published by CASA, individual regulations for various service providers require the implementation of an SMS in their organisations. SMS requirements for Air Transport Operators are detailed in CAO 82.3 for low-capacity regular public transport (LCRPT) and in CAO 82.5 for high-capacity regular public transport (HCRPT), together with CAAP SMS-1, CAAP SMS-2, CAAP SMS-3 and CAAP SMS-4 providing guidance on SMSs, Human Factors (HF), Non-Technical Skills (NTS) training, and assessment and Flight Data Analysis Programs. Regulation on Aerodrome operation on CASR Part 139 and Approved Maintenance Organisations on CASR Part 145 also regulate SMSs in the respective industry sector.

CASA intends to extend the SMS implementation into other aviation service providers including those involved in initial and continuing airworthiness. However, an official notice of the proposed rulemaking has not been published to date.

\subsection{DASA}

With the introduction of the new Defence Aviation Safety Regulations (DASR) by DASA in 2016, a new regulation aligned with the requirements of ICAO Annex 19 has been published as DASR SMS. Other DASR cross refer to the DASR SMS for the purpose of SMS implementation and maintenance by various service providers in the Australian Defence Aviation (ADF) industry. In accordance with DASR SMS, the implementation of SMS is required for holders of Military Air Operator Certificate, DASR Part 21 approved design organisations, DASR Part M Continuing Airworthiness Management Organisations and DASR Part 145 Approved Maintenance Organisations. In comparison with EASA, CASA and FAA, regulations specifically require SMS implementation in initial and continuing airworthiness organisations under the DASR.

\section{Challenges of SMS Implementation in Organisations Involved in Airworthiness}

The main organisations involved in initial and continuing airworthiness functions are the design organisations, the manufacturing (or production) organisations, and continuing airworthiness management organisations. There are common challenges to all aviation organisations and challenges which may be specific to organisations involved in initial and continuing airworthiness functions. These include:

a. Existing research on human error management techniques, tools and error investigation decision aids are mainly in the context of functions related to operational environments [13]. 
Further research needs to be conducted to develop techniques and tools that are more appropriate for airworthiness organisations and specifically applicable for design organisations.

b. Protection of safety data, safety information and related sources, considering the sensitivity of data has not been adequately addressed by all regulators. SMS data could be made public or be required to be produced in civil litigation. ICAO standing is broadly addressed by the "Code of Conduct on the Sharing and Use of Safety Information" documented in the GASP and supplemented by the "Principles for the protection of safety data, safety information and related sources" in Annex 19. Sharing of data should consider the balance between the benefit of sharing versus any adverse effects such as loss of reputation of the organisation, and reduced marketability of services and products.

c. Lack of sufficient safety reports or feedback that affect safety due to various reasons including lack of just culture or reporting culture within either own organisation, or external interfacing organisations.

d. Deficiencies in reporting processes, data management systems, and data analysis tools to make optimal use of safety data.

e. The need to have an integrated approach, with flexibility to integrate existing and proposed programs on safety, quality, security management, and systems engineering to avoid duplication but still ensuring the framework of SMSs are maintained within the context of the airworthiness organisation.

f. Service providers interface with other organisations, and the interface management requirements.

g. The cost burden of additional resources to be allocated to implement SMSs and related activities such as SMS gap analysis, SMS implementation plans, development of organisational procedures, interface management procedures, human resources for new roles, and responsibilities under the SMS and for the provision of SMS training to all staff involved in the processes that affect safety. Cost is dependent on the size and complexity of the organisation and the types of operations and functions carried out by the organisation.

h. Lack of guidance material available for establishing safety targets and safety performance indicators specific for each organisation and operating context.

\section{Benefits of SMS Implementation in Airworthiness Organisations}

In addition to achieving the objective of complying with ICAO Annex 19, implementing SMSs provide various benefits not only to those in operational environments but also to design and production organisations as well as CAMO. SMS as an organised approach to managing safety provides the necessary foundation through organisational structures, accountabilities, policies and procedures, and senior management commitment which is essential for resource allocation [53]. An effective SMS must allocate resources against risk [54], with feedback from the systematic monitoring of key safety performance indicators. Airworthiness organisations will be able to improve on safety performance using the SMS framework correctly. Whilst system safety engineering provides a proven method to ensure the safety of the "design product", SMS enables this to be extended into managing safety through improved organisational structure, processes, procedures, culture, and human error management within the airworthiness organisation. Thus, the safety management of the "product" and "process" as well as the "people" or "human behaviour" are all integrated through SMSs. SMSs also promote scientifically based risk management methods which can be used for product based risks, organisational or process-based risks, and human factor based risks. Costly safety consequences, failures, incidents and accidents can be reduced with proactive risk management and related resource allocation.

In addition to the benefits that can be gained by organisations implementing SMSs, the benefits also extend to aviation authorities. Organisations with a positive safety culture will be more open to safety audits by the regulatory authorities as an external source of information on the safety performance of the organisation [53]. Authorities may have fewer audit findings to administer thereby 
resulting in less time and resources required for follow up on corrective actions. Further to these benefits, EASA Opinion No. 07/2016 [55] discusses the additional benefit of a performance-based approach that can be practiced by design organisations implementing SMS, which would enable EASA to apply a risk-based level of involvement (LOI) in product certification. This is expected to allow EASA to focus its certification resources mainly on areas that need direct and high LOI to more thoroughly verify compliance, while in other certification areas where the risk to safety is assessed to be lower, EASA may rely on approved design organisations, thus optimising the allocation of the agency's resources.

\section{Conclusions}

Review of the regulatory framework for the implementation of SMSs has revealed that the scope of ICAO Annex 19 [3] has recently evolved by recommending the implementation of SMSs in various organisations involved in providing aviation services including organisations responsible for the type design or manufacture of aircraft, engines or propellers. Of the aviation authorities considered in the review, DASA (in its current regulations) and EASA (in its proposed regulations) require SMSs in CAMO, while FAA and Transport Canada do not yet specify SMSs in CAMO. DASA has regulated SMSs for all approved design organisation, while EASA, FAA, and Transport Canada are also in the process of rule-making on this.

ICAO Annex 19 provides a broad framework for implementing SMSs which must be tailored depending on the size and complexity of the organisation and its operations. Furthermore, the context of implementing SMSs and related SMS implementation tools in CAMO and design organisations is different from that in operational environments such as aircraft flying and maintenance. Available techniques and tools for human error management would need to be reviewed for their suitability of application in organisations involved in design and CAMO where further research must be conducted.

Author Contributions: E.B. conceived the study and contributed to all aspects of the paper; J.S. contributed to the introduction, the data analysis, discussion and conclusion; G.W. contributed to the introduction, research design, discussion, and conclusion.

Funding: This research received no external funding.

Conflicts of Interest: The authors declare no conflict of interest.

\section{References}

1. International Civil Aviation Organization. Global Air Transport Outlook to 2030 and Trends to 2040; International Civil Aviation Organization: Montreal, QC, Canada, 2013.

2. International Civil Aviation Organization. Safety Report; International Civil Aviation Organization: Montreal, QC, Canada, 2017.

3. International Civil Aviation Organisation. Annex 19-Safety Management, 2nd ed.; International Civil Aviation Organization: Montreal, QC, Canada, 2016.

4. Coze, L.; Christophe, J. Reflecting on Jens Rasmussen's legacy. A strong program for a hard problem. Saf. Sci. 2015, 71, 123-141. [CrossRef]

5. Rasmussen, J. Skills, rules, and knowledge; signals, signs, and symbols, and other distinctions in human performance models. IEEE Trans. Syst. Man Cybern. 1983, 3, 257-266. [CrossRef]

6. Reason, J. Human Error; Cambridge University Press: Cambridge, UK, 1990.

7. Moriarty, C.D. Practical Human Factors for Pilots; Academic Press: Cambridge, MA, USA, 2014.

8. International Civil Aviation Organization. Doc 9859—Safety Management Manual (DRAFT), 4th ed.; International Civil Aviation Organization: Montreal, QC, Canada, 2017.

9. Stolzer, A.J. Safety Management Systems in Aviation; Routledge: Abingdon, UK, 2017.

10. Allianz. Global Aviation Safety Study; Allianz: Munich, Germany, 2014.

11. Szabo, S.; Koblen, I. Aviation Technology Life Cycle Management: Importance for Aviation Companies, Aerospace Industry Organizations and Relevant Stakeholders. MAD-Mag. Aviat. Dev. 2017, 5, 15-24. [CrossRef] 
12. Kantowitz, B.H.; Casper, P.A. Human workload in aviation. In Human Error in Aviation; Routledge: Abingdon, UK, 2017; pp. 123-153.

13. Dismukes, R.K. Human Error in Aviation; Routledge: Abingdon, UK, 2017.

14. Sarter, N.B.; Mumaw, R.J.; Wickens, C.D. Pilots' monitoring strategies and performance on automated flight decks: An empirical study combining behavioral and eye-tracking data. Hum. Factors 2007, 49, 347-357. [CrossRef] [PubMed]

15. Sarter, N.B.; Woods, D.D. Pilot interaction with cockpit automation II: An experimental study of pilots' model and awareness of the flight management system. Int. J. Aviat. Psychol. 1994, 4, 1-28. [CrossRef]

16. Wickens, C.D.; Goh, J.; Helleberg, J.; Horrey, W.J.; Talleur, D.A. Attentional models of multitask pilot performance using advanced display technology. In Human Error in Aviation; Routledge: Abingdon, UK, 2017; pp. 155-175.

17. Hopkin, V.D. Human Factors in Air Traffic Control; CRC Press: Boca Raton, FL, USA, 2017.

18. Isaac, A.; Shorrock, S.T.; Kirwan, B. Human error in European air traffic management: The HERA project. Reliab. Eng. Syst. Saf. 2002, 75, 257-272. [CrossRef]

19. Kontogiannis, T.; Malakis, S. A proactive approach to human error detection and identification in aviation and air traffic control. Saf. Sci. 2009, 47, 693-706. [CrossRef]

20. Gramopadhye, A.K.; Drury, C.G. Human Factors in Aviation Maintenance: How We Got to Where We Are; Elsevier: Amsterdam, The Netherlands, 2000.

21. Latorella, K.A.; Prabhu, P.V. A review of human error in aviation maintenance and inspection. Int. J. Ind. Ergon. 2000, 26, 133-161. [CrossRef]

22. Teperi, A.-M.; Leppänen, A. Managers' conceptions regarding human factors in air traffic management and in airport operations. Saf. Sci. 2011, 49, 438-449. [CrossRef]

23. Wiegmann, D.A.; Shappell, S.A. Applying the human factors analysis and classification system (HFACS) to the analysis of commercial aviation accident data. In Proceedings of the 11th International Symposium on Aviation Psychology, Columbus, OH, USA, 5-8 March 2001.

24. Wiegmann, D.A.; Shappell, S.A. Human error analysis of commercial aviation accidents: Application of the Human Factors Analysis and Classification System (HFACS). Aviat. Space Environ. Med. 2001, 72, 1006-1016. [PubMed]

25. Wiegmann, D.A.; Shappell, S.A. A Human Error Approach to Aviation Accident Analysis: The Human Factors Analysis and Classification System; Routledge: Abingdon, UK, 2003.

26. Johnson, W.B. Industry experience: Implementing technology. In Proceedings of the 15th Symposium on Human Factors in Maintenance and Inspection, London, UK, 27-29 March 2001.

27. International Civil Aviation Organization. Doc 9859-Safety Management Manual, 3rd ed.; International Civil Aviation Organization: Montreal, QC, Canada, 2013.

28. Rankin, W.; Hibit, R.; Allen, J.; Sargent, R. Development and evaluation of the maintenance error decision aid (MEDA) process. Int. J. Ind. Ergon. 2000, 26, 261-276. [CrossRef]

29. Purton, L.; Clothier, R.; Kourousis, K.; Massey, K. The PBP Bow-Tie framework for the systematic representation and comparison of military aviation regulatory frameworks. Aeronaut. J. 2014, 118, 1433-1452. [CrossRef]

30. International Civil Aviation Organisation. Annex 19-Safety Management, 1st ed.; International Civil Aviation Organization: Montreal, QC, Canada, 2013.

31. TUV Nord Airsight Arge. Research Report EASA.2008/9-Studies on the State of Implementation of the Provisions Contained in ICAO Annex 14 on Aerodromes in the EASA Member States; European Aviation Safety Agency: Cologne, Germany, 2010.

32. International Civil Aviation Organisation. Convention on International Civil. Aviation done at Chicago on the 7th Day of December 1944; International Civil Aviation Organization: Montreal, QC, Canada, 1944.

33. International Civil Aviation Organisation. Doc. 10004-Global Aviation Safety Plan, 2nd ed.; International Civil Aviation Organization: Montreal, QC, Canada, 2016.

34. Two Years Later: An SMS Update. Available online: https://condonlaw.com/2017/05/two-years-later-smsupdate/ (accessed on 20 June 2018).

35. Safety Management International Collaboration Group (SM ICG). Available online: https://www. skybrary.aero/index.php/Safety_Management_International_Collaboration_Group_(SM_ICG) (accessed on 20 June 2018). 
36. DASR—Safety Management System. Available online: http://www.defence.gov.au/DASP/DASRRegulations/SafetyManagementSystem.asp (accessed on 20 June 2018).

37. CASA—Safety Management System—Legislation and Guidance. Available online: https:/ /www.casa.gov. au/education/standard-page/legislation-and-guidance (accessed on 20 June 2018).

38. SMS_EASA Rules. Available online: https://www.easa.europa.eu/easa-and-you/safety-management/ safety-management-system/sms-easa-rules (accessed on 20 June 2018).

39. European Defence Agency. Available online: https:/ / www.eda.europa.eu/home (accessed on 20 June 2018).

40. Federal Aviation Administration-Safety Management System (SMS). Available online: https://www.faa. gov/about/initiatives/sms / (accessed on 20 June 2018).

41. USAF-News Article-Enhancing Air Force Safety Management System. Available online: https:/ / www.safety.af.mil/News / Article-Display / Article/862390/enhancing-air-force-safetymanagement-system-revised-afi-align-mishap-preventio/ (accessed on 20 June 2018).

42. USAF. Air Force Instruction 91-204-Safety Investigation and Hazard. Reporting; USAF: Washington, DC, USA, April 2018.

43. Transport Canada-Safety Management Systems-Implementation Schedule. Available online: http:// www.tc.gc.ca/eng/civilaviation/standards/sms-implementation-617.htm (accessed on 20 June 2018).

44. Federal Aviation Administration (FAA) Regulations. Available online: https://www.faa.gov/regulations_ policies / faa_regulations / (accessed on 20 June 2018).

45. European Aviation Safety Agency (EASA) Regulations. Available online: https://www.easa.europa.eu/ regulations (accessed on 18 October 2018).

46. Society of Automotive Engineers. ARP 4754A Guidelines For. Development of Civil. Aircraft and Systems; SAE: Commonwealth Drive Warrendale, PA, USA, 2010.

47. Society of Automotive Engineers. ARP 4761 Guidelines and Methods for Conducting the Safety Assessment Process on Civil. Airborne Systems and Equipment; SAE: Commonwealth Drive Warrendale, PA, USA, 1996.

48. US Department of Defence. MIL STD 882-E-Standard Practice for System Safety; US Department of Defence: Washington, DC, USA, 2012.

49. EASA. State Safety Program-Phase Implementation Survey Results; EASA: Cologne, Germany, 2014.

50. EASA ToR RMT.0251 (MDM.055) Embodiment of Safety Management Systems (SMS) Requirements into Commission Regulation EU No. 1321/2014—Phase I-SMS in Part M. Available online: https: / / www.easa. europa.eu/document-library/terms-of-reference/tor-mdm055 (accessed on 20 June 2018).

51. EASA ToR RMT.0251(b) (MDM.055-MDM.060)—Embodiment of Safety Management System Requirements into Commission Regulations (EU) No. 1321/2014 and 748/2012 'Phase II-SMS for EASA Part-21 Design Organisations, EASA Part-21 Production Organisations and EASA Part-145 Maintenance Organisations. Available online: https:/ / www.easa.europa.eu/document-library/terms-of-reference-andgroup-compositions/tor-rmt0251b-mdm055-mdm060 (accessed on 20 June 2018).

52. Aerospace Industries Association. Safety Management System Proactices for Design and Production, NAS9927; Aerospace Industries Association: Arlington County, VA, USA, 2015.

53. CASA. SMS for Aviation-A Practical Guide, 2nd ed.; Civil Aviation Safety Authority: Canberra, Australia, 2014.

54. SMS Reconsidered. Available online: https://flightsafety.org/asw-article/sms-reconsidered/ (accessed on 20 June 2018).

55. Opinion 07/2016. Embodiment of Level of Involvement Requirements into Part-21. Available online: https:/ / www.easa.europa.eu/document-library/opinions/opinion-072016 (accessed on 20 June 2018).

(C) 2018 by the authors. Licensee MDPI, Basel, Switzerland. This article is an open access article distributed under the terms and conditions of the Creative Commons Attribution (CC BY) license (http://creativecommons.org/licenses/by/4.0/). 